\title{
Article
}

\section{Mn(II)-based MRI contrast agent candidate for vascular imaging}

Ferenc K. Kalman, Viktoria Nagy, Balázs Váradi, Zolt\&aacute;n Garda, Enik\# Molnár, György Trencsényi, János Kiss, Sandra Même, William Meme, Eva Toth, and Gyula Tircso

J. Med. Chem., Just Accepted Manuscript • DOI: 10.1021/acs.jmedchem.0c00197 • Publication Date (Web): 06 May 2020

Downloaded from pubs.acs.org on May 7, 2020

\section{Just Accepted}

"Just Accepted" manuscripts have been peer-reviewed and accepted for publication. They are posted online prior to technical editing, formatting for publication and author proofing. The American Chemical Society provides "Just Accepted" as a service to the research community to expedite the dissemination of scientific material as soon as possible after acceptance. "Just Accepted" manuscripts appear in full in PDF format accompanied by an HTML abstract. "Just Accepted" manuscripts have been fully peer reviewed, but should not be considered the official version of record. They are citable by the Digital Object Identifier (DOI®). "Just Accepted" is an optional service offered to authors. Therefore, the "Just Accepted" Web site may not include all articles that will be published in the journal. After a manuscript is technically edited and formatted, it will be removed from the "Just Accepted" Web site and published as an ASAP article. Note that technical editing may introduce minor changes to the manuscript text and/or graphics which could affect content, and all legal disclaimers and ethical guidelines that apply to the journal pertain. ACS cannot be held responsible for errors or consequences arising from the use of information contained in these "Just Accepted" manuscripts. 


\section{INTRODUCTION}

Magnetic Resonance Imaging (MRI) has been used in medical diagnosis for its excellent soft tissue imaging capability for decades now. To increase image contrast, MRI relies on contrast agents (CAs). ${ }^{1}$ Recently, many specific molecular imaging probes have been proposed to enable visualization of various biomarkers (peptides, enzyme activity, fluctuation in $\mathrm{pH}, \mathrm{pO}_{2}$, concentration of glucose or metal ions such as $\mathrm{Ca}(\mathrm{II}), \mathrm{Zn}(\mathrm{II}), \mathrm{Cu}(\mathrm{II})$, etc.). ${ }^{2}$ Today, commercially available CAs are all Gd(III) complexes (Gd(III)-based CAs = GBCAs) formed with open-chain (linear) or macrocyclic ligands such as DTPA (diethylenetriamineN,N,N',N',N''-pentaacetate) and DOTA $(1,4,7,10$ tetraazacyclododecane-1,4,7,10-tetraacetic acid) or their derivatives. The lustrous history of MRI CAs seems to be undermined by safety concerns reported in the literature since the early 2000s. The emergence of a potentially fatal disease, Nephrogenic Systemic Fibrosis (NSF) in patients with poor renal function triggered by free $\mathrm{Gd}(\mathrm{III})$ ions released from $\mathrm{CAs}^{3,4}$ prompted a still growing interest to find non-Gd(III) alternatives. Later, from 2014, numerous reports have pointed out that multiple GBCA injections may result in Gd(III) accumulation even in patients with healthy kidney function and receiving exclusively macrocyclic GBCAs. ${ }^{5,6}$ These concerns have led to definite measures form regulatory agencies in Europe (https://www.ema.europa.eu/en). In 2017, the European Medicines Agency (EMA) suspended marketing authorizations for three out of the total five GBCAs based on a linear ligand and restricted the use of two other agents only for liver imaging complying with important diagnostic need. In parallel, the Food

and Drug Administration (FDA) issued a new class of warnings in relation with the use of GBCAs.

For several years, the paramagnetic $\mathrm{Mn}$ (II) has been in the forefront of contrast agent research as it is believed to be one of the most promising alternatives to $\operatorname{Gd}(\mathrm{III}) .{ }^{1}$ Naturally, when applied in high concentration, Mn(II) also displays toxicity. ${ }^{7}$ $\mathrm{Mn}(\mathrm{II})$ accumulation in the brain causes a neurological disorder known as manganism, expressing symptoms similar to Parkinson's disease. ${ }^{8}$ Therefore, $\mathrm{Mn}(\mathrm{II})$-based agents must also be administered in the form of stable and inert complexes. Unfortunately, the thermodynamic stability and kinetic inertness of $\mathrm{Mn}$ (II) complexes are generally lower than that of Gd(III) or other transition metal counterparts, due to the smaller charge and lack of ligand-field stabilization energy (high-spin $d^{5}$ electron configuration). $\mathrm{Mn}$ (II) complexes formed with open-chain ligands are known to be kinetically labile; few exceptions involve the rigid CDTA and its derivatives (i.e. PyC3A) or PhDTA complexes (structure of the ligands mentioned in the text are included in Figure 1) ${ }^{9-11}$ Being an essential metal ion, Mn(II) is efficiently eliminated form the living system, as it was recently demonstrated following injection of the acyclic [Mn(PyC3A)] chelate into rats. ${ }^{12}$ On the other hand, for the majority of macrocyclic $\mathrm{Mn}(\mathrm{II})$ complexes, either low relaxivity (i.e. non aquated, but inert $[\mathrm{Mn}(\mathrm{NOTA})]^{-}$or $\left.[\mathrm{Mn}(\mathrm{DOTA})]^{2-}\right)$ or limited inertness (bisaquated $\mathrm{Mn}(\mathrm{II})$ complexes of 15-membered macrocyclic ligands such as $15 \mathrm{Py}-\mathrm{aneN}_{5}$ or $15 \mathrm{Py}-\mathrm{aneN}_{3} \mathrm{O}_{2}$ ) seem to limit potential in vivo application. ${ }^{13-15}$ A compromise between these seemingly contradictory requirements was recently found with $\mathrm{Mn}(\mathrm{II})$ complexes of 1,4-DO2A and its amide derivatives $\left(1,4-\mathrm{DO} 2 \mathrm{AM}^{\mathrm{Me} 2}\right)$ by $\mathrm{M}$. Botta and coworkers. ${ }^{16,17}$ These stable and inert chelates possess an average of 0.9 bound water molecule.

We propose here to consolidate efficient relaxation enhancement and kinetic inertness by using the pyclen platform for $\mathrm{Mn}(\mathrm{II})$ complexation. Recent data on trisubstituted cyclododecanes have evidenced greater conditional stability for $[\mathrm{Mn}(\mathrm{PCTA})]^{-}$than for $[\mathrm{Mn}(\mathrm{DOTA})]^{2-}(\mathrm{pH}=7.4)$. The kinetic inertness of $[\mathrm{Mn}(\mathrm{PCTA})]^{-}$was also found sufficiently high to allow for further ligand modification, such as reduction of ligand denticity to attain higher hydration number of the $\mathrm{Mn}$ (II) complex. Recently, we have proposed the PC2A-EA ligand as a 
$\mathrm{pH}$ responsive $\mathrm{CA}$ candidate which merges the advantageous $\mathrm{Mn}(\mathrm{II})$ binding properties of PCTA and the $\mathrm{pH}$-responsive "on/off" coordination feature of the ethylamine pendant arm. ${ }^{18}$ Following a similar strategy, we have replaced one acetate arm in PCTA with a biphenyl "anchor", resulting in the hexadentate PC2A-BP chelator (Chart 1., see ESI for other structures discussed). With this, we aimed to preserve strong and inert metal coordination by the $\mathrm{PC} 2 \mathrm{~A}$ chelator, implying monohydration in its $\mathrm{Mn}(\mathrm{II})$ complex, while introducing a hydrophobic moiety with potential targeting capability to Human Serum Albumin (HSA). Recent advances in MR hardware enable high quality MR angiography to be performed with extracellular CAs just seconds after injection, and therefore the development of new angiographic CAs is generally considered less important. ${ }^{19}$ Nevertheless, specific applications, such as highlighting microvascularization in tumors, would largely benefit from efficient angiographic probes, and in general, HSA remains an important target when it comes to targeted imaging applications..$^{20-23}$
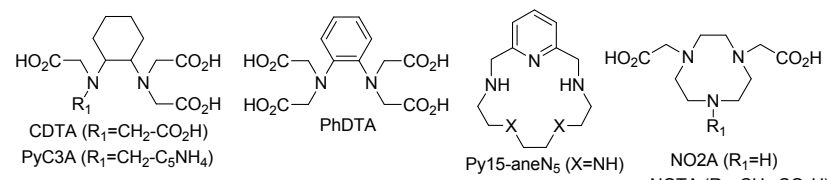

Py15-ane $\mathrm{N}_{5}(X=\mathrm{NH}) \quad \mathrm{NO} 2 \mathrm{~A}\left(\mathrm{R}_{1}=\mathrm{H}\right)$ Py15-ane $\mathrm{N}_{5}(\mathrm{X}=\mathrm{NH})$
Py15-ane $\mathrm{N}_{3} \mathrm{O}_{2}(\mathrm{X}=\mathrm{O}) \quad \mathrm{NOT}\left(\mathrm{R}_{1}=\mathrm{H}\right)$
NOT $\left(\mathrm{R}_{1}=\mathrm{CH}_{2}-\mathrm{CO}_{2} \mathrm{H}\right)$

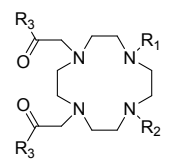

DOTA $\left(\mathrm{R}_{1}=\mathrm{R}_{2}=\mathrm{CH}_{2}-\mathrm{CO}_{2} \mathrm{H}, \mathrm{R}_{3}=\mathrm{OH}\right)$

DO3A $\left(\mathrm{R}_{1}=\mathrm{CH}_{2}-\mathrm{CO}_{2} \mathrm{H}, \mathrm{R}_{2}=\mathrm{H}, \mathrm{R}_{3}=\mathrm{OH}\right)$

1,4-DO2A $\left(\mathrm{R}_{1}=\mathrm{R}_{2}=\mathrm{H}, \mathrm{R}_{3}=\mathrm{OH}\right)$

1,4-DO2AMMe2 $\left(\mathrm{R}_{1}=\mathrm{R}_{2}=\mathrm{H}, \mathrm{R}_{3}=\mathrm{N}\left(\mathrm{CH}_{3}\right)_{2}\right)$

$1,4-\mathrm{DO}_{2} \mathrm{AM}^{\mathrm{Bz}}\left(\mathrm{R}_{1}=\mathrm{R}_{2}=\mathrm{H}, \mathrm{R}_{3}=\mathrm{NH}-\mathrm{CH}_{2}-\mathrm{C}_{6} \mathrm{H}_{5}\right)$

1,4-BzDO2AMMe2 $\left(\mathrm{R}_{1}=\mathrm{R}_{2}=\mathrm{CH}_{2}-\mathrm{C}_{6} \mathrm{H}_{5}, \mathrm{R}_{3}=\mathrm{N}-\mathrm{R}_{3}=\mathrm{N}\left(\mathrm{CH}_{3}\right)_{2}\right)$

DD-DO2A ( $\left.\mathrm{R}_{1}=\mathrm{R}_{2}=\mathrm{C}_{12} \mathrm{H}_{25}, \mathrm{R}_{3}=\mathrm{OH}\right)$

DH-DO2A $\left(\mathrm{R}_{1}=\mathrm{R}_{2}=\mathrm{C}_{16} \mathrm{H}_{33}, \mathrm{R}_{3}=\mathrm{OH}\right)$

Chart 1. Formulae of the ligands mentioned in the text.

The biphenyl substituent is expected to have an additional positive consequence, important for the safety profile of the complex. The presence of bulky aromatic groups (such as benzyl, methyl-biphenyl etc.) should result in lowering the protonation constant of the ligand in agreement with numerous examples of EDTA- and DTPA-derivatives (Table S1), through steric effect, conformational changes, or by altering the lipophilic/lipophobic balance. ${ }^{24-26}$ Moreover, the bulkiness of the substituent should limit the formation of dinuclear intermediates which are important in metal-assisted dissociation pathways, further increasing the kinetic inertness of the $\mathrm{Mn}(\mathrm{II})$ chelate.

We show here that the $[\mathrm{Mn}(\mathrm{PC} 2 \mathrm{~A}-\mathrm{BP})]$ complex retains indeed excellent thermodynamic stability and resistance to dissociation. ${ }^{1} \mathrm{H}$ and ${ }^{17} \mathrm{O}$ NMR relaxometric studies evidence monohydration and efficient relaxation enhancement for the complex. ${ }^{1}$ H-relaxometry was used to show interaction of [Mn(PC2A-BP)] with HSA. Finally, we demonstrate the capability of the agent to efficiently highlight microvascularization in vivo in mice brain.

\section{RESULTS AND DISSCUSSION}

PC2A-BP was prepared by alkylating the bis-methylcyanidepyclen precursor, obtained by following the procedure of Kim et al., with commercially available 1-(chloromethyl)-4phenylbenzene in the presence of DIPEA base and KI. ${ }^{27}$ The product was then hydrolyzed in $6 \mathrm{M} \mathrm{HCl}$ and purified for analytical work by preparative HPLC to give the PC2A-BP chelator (Scheme 1). In order to get insight into solution equilibria of the PC2A-BP ligand and its complexes formed with biologically relevant metal ions (Mg(II), Ca(II), Mn(II), $\mathrm{Zn}(\mathrm{II})$ and $\mathrm{Cu}(\mathrm{II}))$, ligand protonation constants as well as protonation

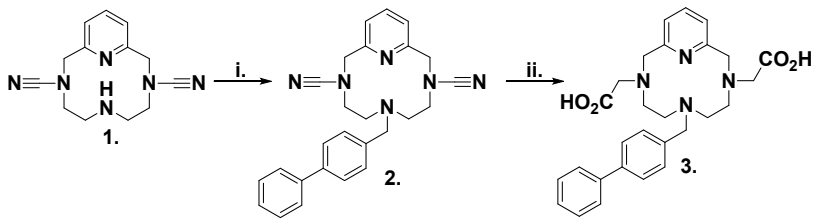

Scheme 1. Synthesis of PC2A-BP ligand: i. 4-phenylbenzyl chloride, DIPEA, KI, MeCN; ii. $\mathrm{HCl}$, than HPLC separation.

and stability constants of the complexes were assessed by $\mathrm{pH}-$ potentiometry and supplemented by ${ }^{1} \mathrm{H}$-relaxometry $(\mathrm{Mn}(\mathrm{II}))$ or UV-vis spectrophotometry $(\mathrm{Cu}(\mathrm{II}))$. Protonation constants of the ligand and stability constants of the PC2A-BP complexes are listed in Table 1 along with the corresponding values for PC2A and PCTA (see equations describing the protonation and complex formation equilibria in the experimental part). PC2A-BP is less basic than $\mathrm{PC} 2 \mathrm{~A}$ which is the consequence of multiple effects (steric, lipophilic/lipophobic equilibrium, changes in conformation or hydrogen binding etc,) associated with the biphenyl unit attached to the nitrogen in trans position with respect to the pyridine. PCTA is even less basic, which can be related to the formation of a relatively stable complex with $\mathrm{Na}^{+}$, present at high concentration (ionic strength). Indeed, the protonation constants determined for PCTA in $1.0 \mathrm{M} \mathrm{KCl}$ are considerably higher than those determined in the current study in $0.15 \mathrm{M} \mathrm{NaCl}^{28}$ The increasing negative charge of the ligands (i.e. increasing number of carboxylate groups capable of binding $\mathrm{Na}^{+}$ ions) is expected to enhance the stability of the $\mathrm{Na}^{+}$complex, as it was also evidenced for cyclen-based chelators which follow the stability order $1,4-\mathrm{DO} 2 \mathrm{~A}<\mathrm{DO} 3 \mathrm{~A}<$ DOTA. ${ }^{13,16}$

Table 1. Protonation constants of the PC2A, PC2A-BP, and PCTA ligands as well as protonation and stability constants of their complexes $\left(25^{\circ} \mathrm{C}, I=0.15 \mathrm{M} \mathrm{NaCl}\right)$.

\begin{tabular}{|c|c|c|c|}
\hline & PC2A-BP & PC2A $^{\mathrm{b}}$ & PCTA $^{\mathrm{e}}$ \\
\hline $\log K_{1}$ & $10.45(2)$ & 12.25 & $9.97 ; 11.36^{\mathrm{f}}$ \\
\hline $\log K_{2}$ & $6.93(3)$ & 5.97 & $6.73 ; 7.35^{\mathrm{f}}$ \\
\hline $\log K_{3}$ & $2.36(4)$ & 3.47 & $3.22 ; 3.83^{\mathrm{f}}$ \\
\hline $\log K_{4}$ & $1.64(4)$ & 1.99 & $1.40 ; 2.12^{\mathrm{f}}$ \\
\hline$\sum \log \beta_{2}{ }^{\mathrm{H}}$ & 17.38 & 18.22 & $16.70 ; 18.71^{\mathrm{f}}$ \\
\hline $\log K_{\mathrm{MgL}}$ & $6.51(6)$ & 9.78 & $12.35^{\mathrm{f}}$ \\
\hline $\log K_{\mathrm{MgL}}{ }^{\mathrm{H}}$ & - & - & $3.82^{\mathrm{f}}$ \\
\hline $\log K_{\mathrm{CaL}}$ & $7.94(2)$ & 9.90 & $12.72^{\mathrm{f}}$ \\
\hline $\log K_{\mathrm{CaL}}{ }^{\mathrm{H}}$ & - & - & $3.79^{\mathrm{f}}$ \\
\hline $\log K_{\mathrm{MnL}}$ & $14.86(1)$ & 17.09 & 16.83 \\
\hline $\log K_{\mathrm{MnL}}{ }^{\mathrm{H}}$ & - & 2.14 & 1.96 \\
\hline $\log K_{\mathrm{ZnL}}$ & $18.05(1)$ & $19.49^{\mathrm{c}}$ & $20.48^{\mathrm{f}}$ \\
\hline $\log K_{\mathrm{ZnL}}{ }^{\mathrm{H}}$ & $1.71(2)$ & $2.74^{\mathrm{c}}$ & $3.10^{\mathrm{f}}$ \\
\hline $\log K_{\mathrm{CuL}}$ & $22.3(2)^{\mathrm{d}}$ & $23.58^{\mathrm{c}}$ & $18.79^{\mathrm{f}}$ \\
\hline $\log K_{\mathrm{CuL}}{ }^{\mathrm{H}}$ & $1.04(3)^{\mathrm{d}}$ & $2.12^{\mathrm{c}}$ & $3.58^{\mathrm{f}}$ \\
\hline $\mathrm{pMnn}{ }^{\mathrm{a}}$ & 8.35 & 8.64 & 9.74 \\
\hline $\mathrm{a}$ & & & \\
\hline
\end{tabular}

a $\mathrm{pMn}=-\log [\mathrm{Mn}(\mathrm{II})], \mathrm{c}_{\mathrm{Mn}(\mathrm{II})}=\mathrm{c}_{\mathrm{lig}}=0.01 \mathrm{mM} ; \mathrm{b}$ V. Nagy, K. Póta, E. Tóth, Z. Garda, J. L. Barriada, R. Tripier, C. Platas- 
Iglesias, É. Tóth, Gy. Tircsó, manuscript in preparation, $25^{\circ} \mathrm{C}$, $I=0.15 \mathrm{M} \mathrm{NaCl}$; ${ }^{\mathrm{c}}$ determined by simultaneous fitting of $\mathrm{pH}-$ pot. and UV-Vis spectrophotometric data; ${ }^{\mathrm{d}}$ determined by UV-Vis spectrophotometry, ${ }^{\mathrm{e}} 25^{\circ} \mathrm{C}, I=0.15 \mathrm{M} \mathrm{NaCl} ;{ }^{\mathrm{f}} \operatorname{Ref}{ }^{28}, 25^{\circ} \mathrm{C}, I=1.0$ $\mathrm{M} \mathrm{KCl} \log K_{5}=1.29$.

The stability constants of the complexes increase with increasing basicity of the ligand except for the $\mathrm{Cu}(\mathrm{II})$ ion, for which the observed anomaly can be explained in terms of a likely underestimated stability constant for the $\mathrm{Cu}(\mathrm{PCTA})$ complex. As it was shown recently for several $\mathrm{Cu}(\mathrm{II})$ complexes formed with macrocyclic ligands, $\mathrm{pH}$ - potentiometric titrations solely (as it was done for the $\mathrm{Cu}(\mathrm{PCTA})$ complex previously) may return erroneous stability constants. ${ }^{29,30}$

PCTA forms a very stable Mn(II) complex and the removal of one metal binding function does not reduce stability (log $K_{\mathrm{MnL}}=16.83$ and 17.09 , for PCTA and PC2A, respectively). However, a noticeable decrease is observed upon the attachment of the electron-withdrawing biphenyl entity to PC2A (log $K_{\mathrm{MnL}}=14.86$ ). The equilibrium model used for the analysis of the $\mathrm{pH}$-potentiometric data has been confirmed with $\mathrm{pH}$ depend ent ${ }^{1} \mathrm{H}$ relaxometry (Fig. S1), which also evidenced complete formation of the $[\mathrm{Mn}(\mathrm{PC} 2 \mathrm{~A}-\mathrm{BP})]$ complex by $\mathrm{pH}=4.5$. For the $\mathrm{Cu}(\mathrm{II})$ system, complex formation is quantitative already at $\mathrm{pH}=1.6$, thus UV-Vis spectrophotometric titration in batch samples (Fig. S2) was used (22 samples in the $\left[\mathrm{H}^{+}\right]$concentration range of $0.003-1.030 \mathrm{M}$, Fig. S2) to obtain the stability constant.

Stability constants alone do not allow comparing the capability of ligands with different basicity to sequester a given metal cation, as metal complexation and ligand protonation are competitive processes. $\mathrm{pM}$ values, defined as $-\log \left[\mathrm{M}^{\mathrm{m}+}\right]_{\text {free }}$, give a more realistic picture about the conditional stability of the complexes at a given $\mathrm{pH}$. The $\mathrm{pMn}$ values calculated at $\mathrm{pH}=7.4$ and $c_{\mathrm{Mn}}=c_{\mathrm{L}}=0.01 \mathrm{mM}^{14}$ for $[\mathrm{Mn}(\mathrm{PC} 2 \mathrm{~A})]$ and [Mn(PC2A-BP)] are almost identical, while it is one order of magnitude higher for $[\mathrm{Mn}(\mathrm{PCTA})]^{-}$. Under these conditions, for [Mn(PC2A-BP)] less than $0.1 \%$ of total $\mathrm{Mn}(\mathrm{II})$ is non-chelated in equilibrium making it one of the most stable monoaquated $\mathrm{Mn}$ (II) complexes reported to date. Indeed, its pM value is very close to that of the highly stable, but non-hydrated $[\mathrm{Mn}(\mathrm{DOTA})]^{2-}$ complex $(\mathrm{pMn}=9.02) .{ }^{13}$

The thermodynamic stability of the $\mathrm{Zn}$ (II) and $\mathrm{Cu}(\mathrm{II})$ complexes is orders of magnitude higher than that of the $\mathrm{Mn}$ (II) analogues (Table 1), in agreement with the Irving-Williams series. For this reason, the inertness of the $\mathrm{Mn}$ (II) complexes designed for MRI applications has to be particularly high to minimize $\mathrm{Mn}(\mathrm{II})$ release that could result from exchange reactions with endogenous ligands and metal ions. The inertness of [Mn(PC2A$\mathrm{BP})$ ] was assessed by monitoring metal exchange reactions in the presence of high (10-40 fold) excess of $\mathrm{Cu}(\mathrm{II})$ ion, in the $\mathrm{pH}$ range 3.3-5.0. Typically, $\mathrm{Mn}$ (II) and $\mathrm{Gd}(\mathrm{III})$ complexes follow analogous dissociation pathways (Scheme S1). These involve (i) spontaneous dissociation, (ii) proton-assisted pathways through the formation of protonated complexes or (iii) metal-assisted dissociation, occurring via direct attack of the exchanging metal ion on the protonated or deprotonated complex and the subsequent formation of a dinuclear intermediate (see SI for detailed description). Under pseudo-first-order conditions as applied in our study, the rate of the decomplexation can be drawn as in eqn. 1:

$$
-\frac{\mathrm{d}[\mathrm{Mn}(\mathrm{PC} 2 \mathrm{~A}-\mathrm{BP})]_{t}}{\mathrm{~d} t}=k_{\mathrm{obs}}[\mathrm{Mn}(\mathrm{PC} 2 \mathrm{~A}-\mathrm{BP})]_{t} \quad \text { Eqn. } 1 .
$$

where $k_{\text {obs }}$ is a pseudo-first-order rate constant and [Mn(PC2A$\mathrm{BP})]_{t}$ is the total concentration of the $\mathrm{Mn}(\mathrm{II})$ chelate.
The $k_{\mathrm{obs}}$ values increase with increasing $\mathrm{H}^{+}$concentration, while remain independent of $\mathrm{Cu}$ (II) concentration, indicating the absence of a metal-assisted pathway (Figure 1). Taking into account the concentration of the protonated and deprotonated complexes $\left([\mathrm{Mn}(\mathrm{PC} 2 \mathrm{~A}-\mathrm{BP})]_{\mathrm{t}}=[\mathrm{Mn}(\mathrm{PC} 2 \mathrm{~A}-\mathrm{BP})]+[\mathrm{Mn}(\mathrm{HPC} 2 \mathrm{~A}-\right.$ $\mathrm{BP})])$ as well as the protonation constant of [Mn(PC2A-BP)] $\left(K_{\mathrm{H}}\right)$, the following rate equation can be derived (eqn. 2):

$$
k_{\mathrm{obs}}=\frac{k_{0}+k_{1}\left[\mathrm{H}^{+}\right]}{1+K_{\mathrm{H}}\left[\mathrm{H}^{+}\right]} \quad \text { Eqn. } 2 .
$$

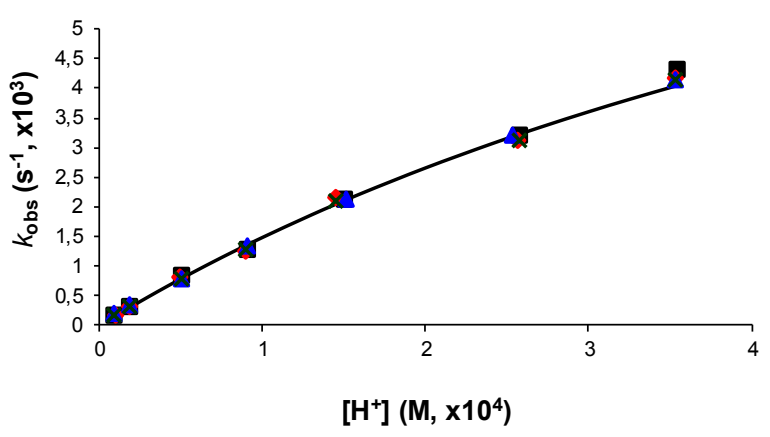

Figure 1. Dependence of the pseudo-first-order rate constants $\left(k_{\mathrm{obs}}\right)$ on the concentration of $\mathrm{H}^{+}$and $\mathrm{Cu}(\mathrm{II})$ ions for the [Mn(PC2A-BP)] complex. The excess of the exchanging metal ion was $\times 10(-\times 20(\diamond), \times 30(\Delta)$ and $\times 40(\times)$ folds. The line corresponds to the best fit of the $k_{\mathrm{obs}}$ values to eqn. 2 .

The fit of the $k_{\mathrm{obs}}$ values to equation 2 revealed that spontaneous dissociation is negligible ( $k_{0}$ is zero). Thus the dissociation of the complex occurs exclusively through the proton-assisted pathway, with a rate constant of $k_{1}=16.9 \pm 0.2 \mathrm{M}^{-}$ ${ }^{1} \mathrm{~s}^{-1}$. The protonation constant of $[\mathrm{Mn}(\mathrm{PC} 2 \mathrm{~A}-\mathrm{BP})]$ obtained is $K_{\mathrm{H}}=1350 \pm 110 \mathrm{M}^{-1}$, one order of magnitude lower than that for $[\mathrm{Mn}(\mathrm{PC} 2 \mathrm{~A})]$, reflecting the lower basicity of PC2A-BP. Nevertheless, the proton-assisted dissociation of [Mn(PC2A-BP)] is over 200 times faster than that of [Mn(PCTA)] $\left(k_{1}{ }^{[\mathrm{Mn}(\mathrm{PCTA})]}=0.082 \mathrm{M}^{-1} \mathrm{~s}^{-1}\right) \cdot{ }^{13}$ In contrast to $[\mathrm{Mn}(\mathrm{PC} 2 \mathrm{~A})]$ and $[\mathrm{Mn}(\mathrm{PCTA})]$, the metal-assisted pathway is not active for $[\mathrm{Mn}(\mathrm{PC} 2 \mathrm{~A}-\mathrm{BP})]$. It is the consequence of the steric hindrance induced by the biphenyl moiety inhibiting any structural reorganization of the $[\mathrm{Mn}(\mathrm{PC} 2 \mathrm{~A}-\mathrm{BP})]$ chelate that would be necessary to form a dinuclear intermediate. The lack of such metal-assisted pathway is responsible for the remarkable inertness of [Mn(PC2A-BP)]. At $\mathrm{pH}=7.4$ and $25^{\circ} \mathrm{C}$, the dissociation halflife is $t_{1 / 2}=286.2$ hours for [Mn(PC2A-BP)], one order of magnitude higher than $t_{1 / 2}=21.0 \mathrm{~h}$ for $[\mathrm{Mn}(\mathrm{PC} 2 \mathrm{~A})]$, though lower than $t_{1 / 2}=5.9 \times 10^{4} \mathrm{~h}$ for [Mn(PCTA)]. The $t_{1 / 2}$ value calculated for $[\mathrm{Mn}(\mathrm{PC} 2 \mathrm{~A}-\mathrm{BP})]$ is the half of that found for the $[\mathrm{Mn}(1,4-$ DO2 $\left.\left.\mathrm{AM}^{\mathrm{Me} 2}\right)\right]^{2+}$ complex, while the $\mathrm{Mn}(\mathrm{II})$ complex formed with a structurally related PC2A-EA ligand appears to be notably more inert $\left(t_{1 / 2}=8 \times 10^{3} \mathrm{~h}\right) \cdot{ }^{17,18}$ Considering a $3-4$-fold acceleration of the dissociation with the increase of temperature on going from 25 ${ }^{\circ} \mathrm{C}$ to $37{ }^{\circ} \mathrm{C}$, one can estimate a half-life $\left(t_{1 / 2}\right)$ of $72-95$ hours for $[\mathrm{Mn}(\mathrm{PC} 2 \mathrm{~A}-\mathrm{BP})]$ at physiological temperature which implies that substantial amount of the complex injected expected to be excreted intact (see SI for details) and the $\mathrm{Mn}$ (II) released in vivo from the complex is estimated to be below $1 \mathrm{mg}$ (when applied at $0.3 \mathrm{mmol} / \mathrm{kg}$ in a $70 \mathrm{~kg}$ patient). Expectedly, the body can handle 
such low amounts of free $\mathrm{Mn}(\mathrm{II})$ without consequences on safety. These considerations are also in full accordance with the results of P. Caravan and co-workers who observed indeed very efficient elimination of the $\mathrm{Mn}(\mathrm{II})$ after injection of $[\mathrm{Mn}(\mathrm{PyC} 3 \mathrm{~A})]^{-}$in rats. ${ }^{12}$ Finally the stability test performed with the use of Seronorm solution have also confirmed the exceptional inertness of the complex (Fig S3).

The water-exchange rate, an important parameter that contributes to efficient relaxation enhancement, was determined by measuring the ${ }^{17} \mathrm{O}$ transverse relaxation rates $\left(1 / T_{2 \mathrm{r}}\right)$ for an aqueous $[\mathrm{Mn}(\mathrm{PC} 2 \mathrm{~A}-\mathrm{BP})]$ solution and a diamagnetic reference at different temperatures (9.4 T, Figure 2). The ${ }^{17} \mathrm{O} 1 / T_{2 \mathrm{r}}$ data were analyzed by the Swift-Connick equations ${ }^{31}$ assuming a simple exponential behavior of the electron spin relaxation (see SI for details). The hydration number was fixed to $q=1$ (based on the proton relaxivity and the maximum ${ }^{17} \mathrm{O} 1 / T_{2 \mathrm{r}}$ value allowing for an estimation of $q=0.9 \pm 0.2$ according to Gale et al. Fig. S4). ${ }^{32}$ The activation energy for the electron spin relaxation and the scalar coupling constant were set to $\mathrm{E}=1 \mathrm{~kJ} / \mathrm{mol}$ and $A_{\mathrm{O}} / \hbar=$ $40 \times 10^{6} \mathrm{rad} \mathrm{s}^{-1}$, respectively following literature recommendations. ${ }^{33}$ The water exchange rate, $k_{\mathrm{ex}}^{298}=(6.3 \pm 0.2) \times 10^{7} \mathrm{~s}^{-1}$, its activation enthalpy, $\Delta H^{\neq}=35.7 \pm 0.1$ $\mathrm{kJ} / \mathrm{mol}$, and the electron spin relaxation rate, $1 / T_{1 \mathrm{e}}^{298}=(4.8 \pm 0.4) \times 10^{7} \mathrm{~s}^{-1}$ were calculated. The contribution of the electron spin relaxation term to the correlation time $1 / \tau_{\mathrm{c}}=k_{\mathrm{ex}}$ $+1 / T_{1 \mathrm{e}}$ is limited at high temperatures $(\sim 8 \%$ at $348 \mathrm{~K})$ which allows for an accurate determination of the water exchange rate. The $k_{\mathrm{ex}}{ }^{298}$ value obtained for [Mn(PC2A-BP)] is slightly higher than value corresponding to the water exchange rate of $[\mathrm{Mn}(\mathrm{PC} 2 \mathrm{~A}-\mathrm{EA})]\left(k_{\mathrm{ex}}{ }^{298}=4.0 \times 10^{7} \mathrm{~s}^{-1}\right),{ }^{18}$ it is the half of that found for $[\mathrm{Mn}(\mathrm{PC} 2 \mathrm{~A})]\left(k_{\mathrm{ex}}{ }^{298}=15.2 \times 10^{7} \mathrm{~s}^{-1}\right)$ and more than 7 times lower than that of $[\mathrm{Mn}(\mathrm{EDTA})]^{2-}\left(k_{\mathrm{ex}}{ }^{298}=47.1 \times 10^{7} \mathrm{~s}^{-1}\right) .{ }^{15}$

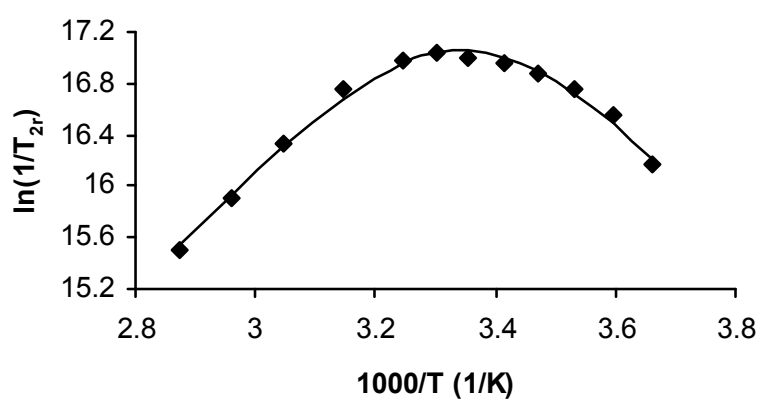

Figure 2. Temperature dependence of the reduced ${ }^{17} \mathrm{O}$ transverse relaxation rates for $[\mathrm{Mn}(\mathrm{PC} 2 \mathrm{~A}-\mathrm{BP})]$ at $9.4 T$ and $\mathrm{pH}$ 7.4. The line corresponds to the best fit of the data.

The difference in the water exchange rate of the $[\mathrm{Mn}(\mathrm{PC} 2 \mathrm{~A}-$ $\mathrm{BP})]$ and $[\mathrm{Mn}(\mathrm{PC} 2 \mathrm{~A})]$ complexes arises from the presence of the biphenyl pendant which can slow down the rearrangement of the coordination cavity during the water exchange process, similarly to triazacyclononane-diacetates (NO2A) bearing aromatic substituents. $^{34}$

In the presence of $0.7 \mathrm{mM} H \mathrm{HSA}$, the relaxivity of [Mn(PC2A$\mathrm{BP})$ ] undergoes a six fold increase (23.5 vs. $3.8 \mathrm{mM}^{-1} \mathrm{~s}^{-1}$ in the absence of HSA; $\left.37{ }^{\circ} \mathrm{C}, 0.49 \mathrm{~T}\right)^{22,23}$, indicating a strong interaction between the $[\mathrm{Mn}(\mathrm{PC} 2 \mathrm{~A}-\mathrm{BP})]$ complex and the protein

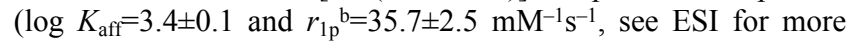
relaxivity data, Fig S5-S8). The $r_{1 \mathrm{p}}^{\mathrm{b}}$ value is lower than those observed for the majority of EDTA-like Mn(II) chelates by M. Botta and coworkers, while other EDTA-based HSA targeting structures showed similar relaxivity and considerably higher (by an order of magnitude) affinity constant (Table S2). ${ }^{22,35}$ Similar relaxivity values $\left(r_{1 \mathrm{p}}{ }^{\mathrm{b}}\right)$ and binding constants were observed, however, for $\mathrm{Mn}$ (II) chelates formed with DO2A-bis(amide) or amphiphilic DO2A derivative ligands (Table 2). ${ }^{22,36}$

Table 2. Comparison of relaxivities (0.49 T MHz; $298 \mathrm{~K}$ ) and HSA binding affinities of selected macrocyclic $\mathrm{Mn}(\mathrm{II})$ complexes.

\begin{tabular}{|c|c|c|c|}
\hline & $\begin{array}{l}\log \\
\left(\mathrm{n} \times K_{\mathrm{aff}}\right)\end{array}$ & $\begin{array}{l}r_{1 \mathrm{p}}\left(\mathrm{mM}^{-}\right. \\
\left.{ }^{1} \mathrm{~S}^{-1}\right)\end{array}$ & $\begin{array}{l}r_{1 \mathrm{p}}^{b}\left(\mathrm{mM}^{-}\right. \\
\left.{ }^{1} \mathrm{~s}^{-1}\right)\end{array}$ \\
\hline$[\mathrm{Mn}(\mathrm{PC} 2 \mathrm{~A}-\mathrm{BP})]$ & $3.4 \pm 0.1$ & $4.96 \pm 0.5$ & $35.7 \pm 2.5$ \\
\hline$\left[\mathrm{Mn}\left(\mathrm{BzDO} 2 \mathrm{AM}^{\mathrm{Me} 2}\right]^{2+}\right.$ & 3.59 & 3.8 & 18.5 \\
\hline$\left[\mathrm{Mn}\left(\mathrm{DO} 2 \mathrm{AM}^{\mathrm{Bz}}\right]^{2+, \mathrm{a}}\right.$ & 3.08 & 3.5 & 27.4 \\
\hline$\left[\mathrm{Mn}(\mathrm{DD}-\mathrm{DO} 2 \mathrm{~A}]^{\mathrm{b}}\right.$ & 4.36 & 12.6 & 29.5 \\
\hline$\left[\mathrm{Mn}(\mathrm{DH}-\mathrm{DO} 2 \mathrm{~A}]^{\mathrm{b}}\right.$ & 4.00 & 15.3 & 27.2 \\
\hline
\end{tabular}

The efficacy of the $[\mathrm{Mn}(\mathrm{PC} 2 \mathrm{~A}-\mathrm{BP})]$ complex as an HSA targeting probe was evaluated in MRI experiments at $3 \mathrm{~T}$ magnetic field strength by using phantoms with $0.20 \mathrm{mM}$ complex in seronorm or in the presence of $0.7 \mathrm{mM}$ HSA (Fig $\mathrm{S} 10)$. Analysis of the MR images indicate that the signal intensity changes notably on going form $[\mathrm{Mn}(\mathrm{CDTA})]^{2-}$ to $[\mathrm{Mn}(\mathrm{PC} 2 \mathrm{~A}-$ $\mathrm{BP})$ ] alone, but more pronounced brightening of $T_{1}$ images is observed when the HSA (or other proteins present in the serum) appears in the sample.

HSA is an important protein target for angiographic imaging and the potential of $[\mathrm{Mn}(\mathrm{PC} 2 \mathrm{~A}-\mathrm{BP})]$ for the visualization of the vascular system has been demonstrated in an angiographic MRI study in Swiss mice. ${ }^{19,37}$ MR dynamic contrast enhanced (DCE) imaging has been performed in Swiss mice to follow the biodistribution of $[\mathrm{Mn}(\mathrm{PC} 2 \mathrm{~A}-\mathrm{BP})]$. After the injection of the complex, there is an immediate increase in signal intensity in the kidney, followed by a decrease. This indicates that a part of the contrast agent is excreted via the kidneys. This elimination phase is quicker than that for the Dotarem, a GBCA used in clinical practice ([Gd(DOTA)]Meg). In parallel, intensity also increases in the liver and remains constant for a period of 15 minutes (Fig. S10). This is likely the cumulative effect of some hepatocellular uptake and the presence of the agent in the blood vessels of the highly vascularized liver. The signal intensity increase in the liver is less pronounced than that in the kidney medulla. Vascular cerebral blood flow was measured by Magnetic Resonance Angiography (MRA) using a Fast Low Angle Shot (FLASH) sequence at an injected dose of $25 \mu \mathrm{mol} / \mathrm{kg}$ of [Mn(PC2A-BP)], which is 4 times smaller than the standard dose of the Gd(III)based MRI CAs used for clinical experiments. [Mn(PC2A-BP)] provided a substantial increase in blood signal that allowed the visualization of brain vascularization in more details than without
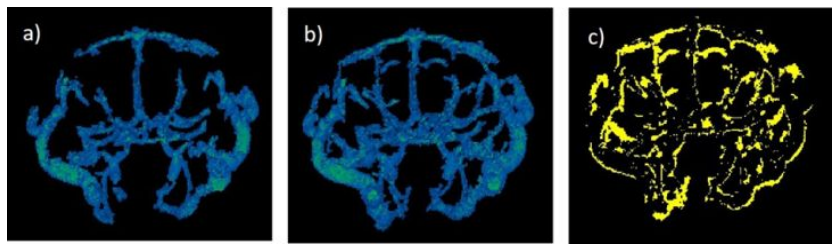

Figure 3. Angiographic MR images of a Swiss mouse brain acquired (a) before and (b) $30 \mathrm{~min}$ after i.v. administration of 
[Mn(PC2A-BP)] at a dose of $25 \mu \mathrm{mol} / \mathrm{kg}$, using a FLASH sequence $(\mathrm{FOV}=1.83 * 1,83 \mathrm{~cm}, \mathrm{x} 14 \mathrm{~mm} 2$, matrix $=256 \times 256$, $T R / T E=30 / 5 \mathrm{~ms}, 51$ axial slices $0.2 \mathrm{~mm}$ thickness, $\mathrm{NA}=4$, experimental time $=13 \mathrm{~min}$ ). (c) Signal intensity increase observed at $30 \mathrm{~min}$ post-injection with respect to the pre-injection angiographic MR image.

the CA. It highlighted micro-vascularization which was invisible without injecting the chelate as demonstrated in Figure 3 which represents pre- and post-injection angiographic MR images as well as the signal intensity difference between the two. The increase in blood signal intensity was retained even 30 minutes after the injection, and could be quantified as $+26 \%$ at this time point with respect to the signal intensity prior to injection. MRA can be typically performed without the use of contrast agents or with extracellular fluid agents like Magnevist ([Gd(DTPA) $\mathrm{Meg}_{2}$ ) and Dotarem by imaging few seconds after injection during the first pass of the agent through the vasculature. ${ }^{19}$ Nevertheless, a substantial improvement in highlighting the microvessels, otherwise invisible, and the extension of the time window available for imaging can be beneficial in certain cases, such as in characterizing the tumor vascularization.

\section{CONCLUSION}

In conclusion, we have demonstrated that the PC2A platform and in particular the PC2A-BP is a promising chelator for $\mathrm{Mn}(\mathrm{II})$. The chemical design involving a bulky substituent on the macrocycle nitrogen prevents metal-assisted dissociation pathways and induces remarkable inertness $\left(t_{1 / 2}=286.2\right.$ hours at 25 $\left.{ }^{\circ} \mathrm{C}\right)$. This, combined with an excellent thermodynamic stability $\left(\log K_{[\mathrm{Mn}(\mathrm{PC} 2 \mathrm{~A}-\mathrm{BP})]}=14.86, \mathrm{pMn}=8.35\right)$, minimizes potential in vivo metal release (based on serum stability studies it is estimated below $0.05 \%)$. The high relaxivity observed in the presence of $0.7 \mathrm{mM} \mathrm{HSA}\left(r_{1 \mathrm{p}}=23.5 \mathrm{mM}^{-1} \mathrm{~s}^{-1}, 20 \mathrm{MHz}, 37{ }^{\circ} \mathrm{C}\right)$ allows to considerably lower the injected dose of the CA $(25 \mu \mathrm{mol} / \mathrm{kg})$ and yet to obtain excellent visualization of the mouse brain vasculature.

\section{EXPERIMENTAL SECTION}

General Remarks. Starting commercial reagents/solvents were purchased from Sigma-Aldrich (St. Louis, MO, USA), Tokyo Chemical Industry (Tokyo, Japan) and Fluorochem (Hadfield, Glossop, UK) and were used without further purification unless otherwise stated. Deionized Milli-Q ${ }^{\circledR}$ water was used for the preparation of all aqueous solutions (equilibrium/kinetic/relaxometric studies). ${ }^{1} \mathrm{H}$ NMR spectra were recorded on a Bruker Avance 360 or $400 \mathrm{MHz}$ spectrometer (chemical shifts are given as $\delta$ values with reference to tetramethylsilane and coupling constants are reported in $\mathrm{Hz}$ ). Mass spectroscopic characterization of the product was performed in the Laboratory of Instrumental Analysis, Department of Organic Chemistry of the University of Debrecen equipped with Thermo Accela 600 UPLC system coupled with LTQ-XL mass spectrometer. Prior to its use in the analytical experiments, the final product was purified by preparative high-pressure liquid chromatography (HPLC). Analytical HPLC was performed with the a Waters Alliance 2690 HPLC (Waters Inc., USA) system equipped with a Luna $\mathrm{C} 18(2) 150 \mathrm{~mm} \times 4.6 \mathrm{~mm}, 100 \AA, 5 \mu \mathrm{m}$ column (Phenomenex Inc., USA), at $25{ }^{\circ} \mathrm{C}$ temperature, with a flow rate of $1.00 \mathrm{~mL} / \mathrm{min}$. Preparative separations were performed using HPLC technique (YL9100 HPLC, Korea) equipped with a Luna C18(2) column $(250 \mathrm{~mm} \times 21.2 \mathrm{~mm}, 100 \AA$, $5 \mu \mathrm{m}$, Phenomenex Inc. USA). The solvent flow rate in this case was $25.00 \mathrm{~mL} / \mathrm{min}$ using gradient elution as follows: eluent A (5 $\mathrm{mM}$ TFA in water) and $\mathrm{B}(\mathrm{ACN})$; gradient: $15 \% \mathrm{~B}$ to $40 \% \mathrm{~B}$ in
$7.50 \mathrm{~min}$. The purity of the product was $>99.8 \%$ determined by reverse-phase HPLC with UV-vis detection at 210 and $260 \mathrm{~nm}$ (Fig. S12).

Synthesis of the PC2A-BP ligand. The PC2A-BP ligand was prepared by alkylating the bis-methylcianide-pyclen precursor (3,9-bis(methylenenitrile)-3,6,9,15-tetraazabicyclo[9.3.1]pentadecal(1S),11,13-triene 1) prepared by following the procedure of Kim et al. ${ }^{27}$ with the commercially available 4-phenylbenzyl chloride in the presence of Hüning's base as follows: $150 \mathrm{mg}$ $(0,528 \mathrm{mmol})$ of bis-methylcianide-pyclen (1) was dissolved in 5 $\mathrm{mL}$ of dry acetonitrile under Ar protected atmosphere and 0.185 $\mathrm{ml}(1.06 \mathrm{mmol})$ of Hüning's base ( $N, N$-diisopropylethylamine, DIPEA) as well as $45 \mathrm{mg}(0,268 \mathrm{mmol})$ of KI was added to the solution. The reaction mixture was heated to $60{ }^{\circ} \mathrm{C}$ by using an oil bath and $0.118 \mathrm{~g}(0.580 \mathrm{mmol})$ of 4-phenylbenzyl chloride dissolved in $5 \mathrm{~mL}$ of dry acetonitrile was added to the suspension dropwise during 3 hours. The reaction mixture was stirred at the given temperature for 40 hours, filtered and the filtrate evaporated to dryness under reduced pressure. The oily residue was redissolved in $10 \mathrm{~mL}$ of $12 \mathrm{M} \mathrm{HCl}$ and the solution was refluxed for $25 \mathrm{~h}$ at $110^{\circ} \mathrm{C}$. The reaction mixture was then evaporated to dryness under reduced pressure and the residue was redissolved in $4 \mathrm{~mL}$ of double distilled water. Separation via preparative HPLC (Fig. S12) yielded PC2A-BP as off white solid upon freeze-drying the combined fractions containing the product. Yield $144 \mathrm{mg}$ $(81 \%)$.

${ }^{1} \mathrm{H}-\mathrm{NMR}$ (Fig. S13): (360,13 MHz, $\left.\mathrm{D}_{2} \mathrm{O}\right) \delta=3.16(\mathrm{~m} \mathrm{4H},>\mathrm{N}-$ $\mathbf{C H}_{2}-\mathrm{CH}_{2}$ ) 3.38 (m 4H, $\left.>\mathrm{N}-\mathrm{CH}_{2}-\mathbf{C H}_{2}-\right) 3.74$ (s $4 \mathrm{H},>\mathrm{N}-\mathbf{C H}_{2-}$ $\mathrm{COOH}) 4.26$ (s $\left.2 \mathrm{H},>\mathrm{N}-\mathbf{C H}_{2}-\mathrm{C}_{12} \mathrm{H}_{9}\right) 4.52$ (s $\left.4 \mathrm{H},>\mathrm{N}-\mathbf{C H}_{2}-\mathrm{Py}\right)$ 7.44 (t 1H, -CH-CH-CH- $\left.\left(\mathrm{C}_{12} \mathrm{H}_{9}\right)\right) 7.53$ (m 2H, -CH-CH-CH$\left.\left(\mathrm{C}_{12} \mathrm{H}_{9}\right)\right) 7.62\left(\mathrm{~d} 4 \mathrm{H},-\mathbf{C H}-\mathbf{C H}-\left(\mathrm{C}_{12} \mathrm{H}_{9}\right)\right) 7.72(\mathrm{~m} 2 \mathrm{H},-\mathbf{C H}-\mathrm{CH}-$ CH- (Py)) 7.73 (m 2H, -CH-C-CH- $\left.\left(\mathrm{C}_{12} \mathrm{H}_{9}\right)\right) 8.19$ (t 1H, -CHCH-CH- (Py)).

${ }^{13} \mathrm{C}-\mathrm{NMR}$ (Fig. S13): $\left(100 \mathrm{MHz}, \mathrm{D}_{2} \mathrm{O}\right) \delta=51.6(4 \mathrm{C}, 2 \mathrm{p}>\mathrm{N}-$ $\left.\mathbf{C H}_{2}-\mathbf{C H}_{2}-\right)$ 56.6 (4C, $2 \mathrm{p}>\mathrm{N}-\mathbf{C H}_{2}-\mathrm{COOH}$ and $\left.2 \mathrm{p}>\mathrm{N}-\mathbf{C H}_{2}-\mathrm{Py}\right)$ $58.1\left(1 \mathrm{C},>\mathrm{N}-\mathbf{C H}_{2}-\mathrm{C}_{12} \mathrm{H}_{9}\right) 123.8(2 \mathrm{C},-\mathbf{C H}-\mathrm{CH}-\mathbf{C H}-(\mathrm{Py})) 127.1$ $\left(1 \mathrm{C},-\mathrm{CH}-\mathbf{C H}-\mathrm{CH}-\left(\mathrm{C}_{12} \mathrm{H}_{9}\right)\right) 127.8$ (4C, $\left.2 \mathrm{p}-\mathbf{C H}-\mathrm{C}-\mathbf{C H}-\left(\mathrm{C}_{12} \mathrm{H}_{9}\right)\right)$ 128.3 (1C, -CH-CH-CH- (Py)) $129.3\left(2 \mathrm{C}\right.$, -CH-CH-CH- $\left(\mathrm{C}_{12} \mathrm{H}_{9}\right)$ ) $131.8\left(2 \mathrm{C},-\mathbf{C H}-\mathrm{C}\left(\mathrm{CH}_{2}\right)-\mathbf{C H}-\left(\mathrm{C}_{12} \mathrm{H}_{9}\right)\right) 139.7\left(1 \mathrm{C},-\mathrm{CH}-\mathbf{C}\left(\mathrm{CH}_{2}\right)-\right.$ $\left.\mathrm{CH}-\left(\mathrm{C}_{12} \mathrm{H}_{9}\right)\right) 143.6\left(2 \mathrm{C}, 2 \mathrm{p}-\mathrm{CH}-\mathrm{C}-\mathrm{CH}-\left(\mathrm{C}_{12} \mathrm{H}_{9}\right)\right) 151.5(2 \mathrm{C}, 2 \mathrm{p}-$ $\left.\mathrm{CH}_{2}-\mathrm{C}-\mathrm{N}_{\mathrm{py}}\right) 163.1(2 \mathrm{C}, 2 \mathrm{p}-\mathrm{COOH})$.

\section{MS (ESI) m/z 489,25(M+H) ${ }^{+} 100 \% ; 542,17(\mathrm{M}+\mathrm{Na})^{+} 15 \%$.}

Thermodynamic studies. The highest analytical grade chemicals were used for the studies. The concentration of the metal chloride stock solutions were determined by complexometric titration with the use of standardized $\mathrm{Na}_{2} \mathrm{H}_{2}$ EDTA and xylenol orange $\left(\mathrm{ZnCl}_{2}\right)$, murexid $\left(\mathrm{CuCl}_{2}\right)$, Patton \& Reeder $\left(\mathrm{CaCl}_{2}\right)$ and Eriochrome Black $\mathrm{T}\left(\mathrm{MgCl}_{2}\right.$ and $\mathrm{MnCl}_{2}$ ) as indicator. Equilibrium studies were performed by $\mathrm{pH}-$ potentiometry, with complementary methods applied for $\mathrm{Cu}$ (II) (UV-vis) and $\mathrm{Mn}(\mathrm{II})$ ( ${ }^{1} \mathrm{H}$-relaxometry) complexes. Methrohm 888 Titrando titration workstation with a Metrohm-6.0233.100 combined electrode were used to perform the $\mathrm{pH}$-potentiometric titrations. The titrated solutions $(6.00 \mathrm{~mL})$ were stirred and thermostated $\left(25^{\circ} \mathrm{C}\right)$ in inert gas $\left(\mathrm{N}_{2}\right)$ atmosphere to avoid the effect of $\mathrm{CO}_{2}$. For the calibration of the combined electrode, $\mathrm{KH}-$ phthalate $(\mathrm{pH}=4.005)$ and borax $(\mathrm{pH}=9.177)$ buffers were used. The $\mathrm{pH}$-potentiometric titrations were carried out at constant ionic strength $(0.15 \mathrm{M} \mathrm{NaCl})$. For determining the concentration and protonation constants of the $\mathrm{H}_{2} \mathrm{PC} 2 \mathrm{~A}-\mathrm{BP}$ ligand, $\mathrm{pH}$ potentiometric titrations were made by using $0.2 \mathrm{M} \mathrm{NaOH}$ in 2 $\mathrm{mM}$ ligand solutions. $\mathrm{pH}$-potentiometry was also used to 
determine the protonation and stability constants of the metal complexes (except for $\mathrm{Cu}(\mathrm{II})$ ) where the metal-to-ligand ratio was $1: 1$. The concentration of the ligand and metal ion was generally 2 $\mathrm{mM}$. For the calculation of the protonation and stability constants $80-120 \mathrm{~mL}-\mathrm{pH}$ data pairs obtained in the $\mathrm{pH}$ range of 1.7-12.0, were used. By fitting the $\mathrm{mL}-\mathrm{pH}$ data pairs collected in the ligand titrations to Equation 3, the protonation constants of the ligand were calculated.

$$
K_{\mathrm{i}}^{\mathrm{H}}=\frac{\left[\mathrm{H}_{\mathrm{i}} \mathrm{L}\right]}{\left[\mathrm{H}_{\mathrm{i}-1} \mathrm{~L}\right]\left[\mathrm{H}^{+}\right]} \text {where } \mathrm{i}=1-4 \quad \text { Eqn. } 3
$$
$0.49 \mathrm{~T}$ and $1.41 \mathrm{~T}$ (corresponding to $20 \mathrm{MHz}$ and $60 \mathrm{MHz}$ proton Larmor frequency, respectively). The temperature of the sample holder was set $\left(25.0 \pm 0.2^{\circ} \mathrm{C}\right.$ or $\left.37.0 \pm 0.2^{\circ} \mathrm{C}\right)$ and controlled with the use of a circulating water bath. The $T_{1}$ values were determined with the inversion recovery method $\left(180^{\circ}-\tau-90^{\circ}\right)$ by averaging 46 data points obtained at 10 different $\tau$ delay values. The transverse relaxation times $\left(T_{2}\right)$ were measured by using the CarrPurcell-Meiboom-Gill sequence (CPMG) sequence by averaging again 4-6 identical data points. The $r_{1 \mathrm{p}}$ and $r_{2 \mathrm{p}}$ relaxivities of the complex were determined by using batch samples (in the concentration range of 0.05-1.05 $\mathrm{mM}$ ) prepared under nitrogen atmosphere having the ligand present at slight excess. The $\mathrm{pH}$ in these samples was kept constant at $\mathrm{pH}=7.30$ with the use of 20 mM HEPES buffer $\left(I=0.15 \mathrm{M} \mathrm{NaCl}, 25^{\circ} \mathrm{C}\right)$.

Determination of the affinity constant for the [Mn(PC2ABP)]-HSA system. The binding constants of the [Mn(PC2A-BP)] with HSA was determined following published literature. ${ }^{40}$ The nonlinear increase of the proton paramagnetic relaxation rates measured at $0.49 \mathrm{~T}$ in solutions containing $0.204 \mathrm{mM}$ complex was titrated with HSA. The diamagnetic relaxivity of the water protons and HSA in aqueous solution was taken into account during the calculation.

${ }^{17} \mathrm{O}$ NMR data acquisition. To assess the water exchange rate of the $\mathrm{Mn}$ (II) complex, ${ }^{17} \mathrm{O}-\mathrm{NMR}$ studies were performed on a Bruker Avance $400 \mathrm{MHz}(9.4 \mathrm{~T}, 54.2 \mathrm{MHz})$ spectrometer. $T_{1}$ and $T_{2}$ relaxation times and chemical shifts of an aqueous solution of the $\mathrm{Mn}(\mathrm{II})$ complex ( $\mathrm{pH}=8,00.45 \mathrm{mM})$ and of a diamagnetic reference $\left(\mathrm{HClO}_{4}\right.$ acidified water, $\left.\mathrm{pH}=3.3\right)$ were measured in the temperature range $273-348 \mathrm{~K}$. In order to avoid the oxidation of the $\mathrm{Mn}(\mathrm{II})$ ion in the complex solution hydroxyl-amine was added to the sample (10 $\mathrm{mM}$ concentration). The temperature was determined according to previous calibration routines by means of ethylene glycol as standard. $T_{1}$ and $T_{2}$ relaxation times were determined by the inversion-recovery and the CPMG spin-echo technique, respectively The technique of the ${ }^{17} \mathrm{O}$ NMR measurements has been described previously. ${ }^{41,42}$ To avoid susceptibility corrections of the chemical shifts, a glass sphere fitted into a $10 \mathrm{~mm}$ NMR tube was used during the measurements. The sensitivity of ${ }^{17} \mathrm{O}$-NMR measurements ${ }^{17} \mathrm{O}$ enriched water $(10$ $\% \mathrm{H}_{2}{ }^{17} \mathrm{O}$, CortecNet) was added to the solutions to reach a $2 \%$ enrichment. The fit of the ${ }^{17} \mathrm{O}$ NMR data was performed using Micromath Scientist calculation program via least squares fitting procedure.

MR dynamic contrast enhanced imaging (DCE) for contrast agent biodistribution. Animal experiments were performed at Centre de Biophysique Moléculaire (CBM CNRS UPR431) in Orléans, France in accordance to national and European laws and regulations. The project received approval from the "Ministère de l'enseignement supérieur de la recherche et de l'innovation" under the authorization number 20366. We conform to the Council Directive of 24 November 1986 on The Approximation Of Laws, Regulations And Administrative Provisions Of The Member States Regarding The Protection Of Animals Used For Experimental And Other Scientific Purposes (86/609/Eec and 2010/63/EU).

Eight week old female Swiss mice (RjOrl:SWISS, Janvier Labs) were used for the study. During the MR experiments, the mice were positioned in a custom-built cradle to immobilize the body. They were anesthetized during the MR experiment with $1.5 \%$ isoflurane and a mixture of $\mathrm{O}_{2} /$ air $(1: 1)$ with an output of 0.5 $1 /$ min. Respiration was monitored during the whole experiment using an air pillow and body temperature was maintained constant at $37{ }^{\circ} \mathrm{C}$ by a warm-water circulation system. MR acquisitions were performed on a $7 \mathrm{~T}$ horizontal ultra shielded superconducting magnet dedicated to small animal imaging (70/16 Bruker Pharmascan, Wissembourg, France) and equipped 
with a $230 \mathrm{mT} / \mathrm{m}$ gradient set. A Bruker $38 \mathrm{~mm}$ inner diameter bircage coil was used for both $1 \mathrm{H}$ transmission and reception. The [Mn(PC2A-BP)] $(150 \mu 1,2 \mathrm{mM}, \mathrm{pH}=7.4)$ was injected through a catheter placed in the tail vein. The DCE experiment consisted of a $T_{1}$-weighted IR TrueFisp Bruker sequence (FOV $=3 * 3 \mathrm{~cm}$, matrix $=128 * 96, T_{\mathrm{R}} T_{\mathrm{E}}=3 / 1.5 \mathrm{~ms}$, slice thickness $\left.=1 \mathrm{~mm}\right)$. One sagittal $T_{1}$-weighted image was acquired every 5 seconds during $15 \mathrm{~min}$. The contrast agent was manually injected $1 \mathrm{~min}$ after the beginning of the acquisition. Grey level means in the kidney cortex and medulla were plotted as a function of time during 15 minutes.

Magnetic Resonance Angiography (MRA). Measurements of vascular cerebral blood flow were performed by MRA using a Fast Low Angle Shot (FLASH) sequence, with the following parameters: $\mathrm{FOV}=1.83 * 1,83 \mathrm{~cm}, \mathrm{x} 14 \mathrm{~mm}^{2}$, matrix $=256 \times 256$, $T_{\mathrm{R}} T_{\mathrm{E}}=30 / 5 \mathrm{~ms}, 51$ axial slices $0.2 \mathrm{~mm}$ thickness, NA $=4$, experimental time $=13 \mathrm{~min}$. Angiograms were produced by generating maximum intensity projection (MIP) images after interpolating raw data to obtain an isotropic resolution $\left(109 \mu \mathrm{m}^{3}\right)$. This sequence was performed before, $15 \mathrm{~min}$ and $30 \mathrm{~min}$ after contrast agent injection.

\section{AUTHOR INFROMATION}

\section{Corresponding Authors}

E-mail: $\quad$ eva.jakabtoth@cnrs.fr gyula.tircso@science.unideb.hu (Gy.T.)

(E.T.) and

Notes

The authors declare no competing financial interests.

\section{ASSOCIATED CONTENT}

\section{Supporting Information}

Additional experimental details (including ${ }^{1} \mathrm{H}$ - and ${ }^{13} \mathrm{C}-\mathrm{NMR}$ spectra, HPLC trace etc. for PC2A-BP ligand); a scheme illustrating the dissociation mechanism of a $\mathrm{Mn}$ (II) chelate; determination of relaxivity at 0.49 and $7 \mathrm{~T}, \mathrm{pH}$-profile of the relaxivity; determination of the binding constant for the HSA adduct and binding constants of other $\mathrm{Mn}(\mathrm{II})$ chelates; determination of the number of bound water molecules in [Mn(PC2A-BP)] chelate; NMRD profiles obtained in the absence and presence of HSA; equations used during the fitting of ${ }^{1} \mathrm{H}$ - and ${ }^{17} \mathrm{O}-$-relaxometric data and additional results of phantom and in vivo (DCE) MRI studies. This material is available free of charge via the Internet at http://pubs.acs.org.

\section{ACKNOWLEDGMENT}

The authors acknowledge financial support of the Hungarian National Research, Development and Innovation Office (NKFIH K120224 project), the János Bolyai Research Scholarship of the Hungarian Academy of Sciences (G. T. and F. K. K.), the COST Action CA15209 European Network on NMR Relaxometry and the French National Research Agency (ANR, MANGA CE180008-01). The research was also supported in a part by the EU and co-financed by the European Regional Development Fund under the projects GINOP-2.3.2-15-2016-00008 and GINOP2.3.3-15-2016-00004 and by the ÚNKP-18-4 New National Excellence Program (Gy. T. and F. K. K.) of the Ministry of Human Capacities.

\section{ABBREVIATIONS USED}

DTPA, diethylenetriamine- $\mathrm{N}, \mathrm{N}, \mathrm{N}$ ',N",N"'-pentaacetate; DOTA, 1,4,7,10-tetraazacyclododecane-1,4,7,10-tetraacetic acid; CA, Contrast Agent; GBCA, Gd-Based Contrast Agents; NSF,
Nephrogenic Systemic Fibrosis; EMA, European Medicines Agency; CPMG sequence, Carr-Purcell-Meiboom-Gill sequence; $1 / T_{2 r}$, transverse relaxation rate; DCE imaging, dynamic contrast enhanced imaging; MRA, Magnetic Resonance Angiography; FLASH sequence, Fast Low Angle Shot sequence; FOV, field-ofview; MIP, maximum intensity projection; DIPEA, $N, N$ diisopropylethylamine; MES, 2-( $N$-morpholino)ethanesulfonic acid; DMP, $N, N$ '-dimethyl-piperazine, HEPES, 2-[4-(2hydroxyethyl)piperazin-1-yl]ethanesulfonic acid;

\section{REFERENCES}

(1) Doan, B-T.; Meme, S.; Beloeil, J-C. General Principles of MRI. In The Chemistry of Contrast Agents in Medical Magnetic Resonance Imaging; Merbach, A., Helm, L., Tóth, É., Eds.; Second edition, John Wiley \& Sons Ltd: Chichester, UK, 2013; Vol. 1, pp 1-24.

(2) Parrott, D.; Fernando, W. S.; Martins, A. F. Smart MRI Agents for Detecting Extracellular Events In Vivo: Progress and Challenges. Inorganics 2019, 7, 18.

(3) Grobner, T. Gadolinium - a Specific Trigger for the Development of Nephrogenic Fibrosing Dermopathy and Nephrogenic Systemic Fibrosis? Nephrol. Dial. Transpl. 2006, 21, 1104-1108.

Darrah, T. H.; Prutsman-Pfeiffer, J. J.; Poreda, R. J.; Ellen Campbell, M.; Hauschka, P. V.; Hannigan, R. E. Incorporation of Excess Gadolinium into Human Bone from Medical Contrast Agents. Metallomics 2009, 1, 479. Kanal, E.; Tweedle, M. F. Residual or Retained Gadolinium: Practical Implications for Radiologists and Our Patients. Radiology 2015, 275, 630-634.

Kanda, T.; Fukusato, T.; Matsuda, M.; Toyoda, K.; Oba, H.; Kotoku, J.; Haruyama, T.; Kitajima, K.; Furui, S. Gadolinium-Based Contrast Agent Accumulates in the Brain Even in Subjects without Severe Renal Dysfunction: Evaluation of Autopsy Brain Specimens with Inductively Coupled Plasma Mass Spectroscopy. Radiology 2015, 276, 228-232.

(7) Pan, D.; Schmieder, A. H.; Wickline, S. A.; Lanza, G. M. Manganese-Based MRI Contrast Agents: Past, Present, and Future. Tetrahedron 2011, 67, 8431-8444.

(8) Cersosimo, M. G.; Koller, W. C. The Diagnosis of Manganese-Induced Parkinsonism. NeuroToxicology 2006, 27, 340-346.

(9) Pota, K.; Garda, Z.; Kálmán, F. K.; Barriada, J. L.; Esteban-Gómez, D.; Platas-Iglesias, C.; Tóth, I.; Brücher, E.; Tircsó, G. Taking the next Step toward Inert $\mathrm{Mn}^{2+}$ Complexes of Open-Chain Ligands: The Case of the Rigid PhDTA Ligand. New J. Chem. 2018, 42, 80018011.

(10) Kálmán, F. K.; Tircsó, G. Kinetic Inertness of the $\mathrm{Mn}^{2+}$ Complexes Formed with AAZTA and Some Open-Chain EDTA Derivatives. Inorg. Chem. 2012, 51, 1006510067.

(11) Gale, E. M.; Atanasova, I. P.; Blasi, F.; Ay, I.; Caravan, P. A Manganese Alternative to Gadolinium for MRI Contrast. J. Am. Chem. Soc. 2015, 137, 15548-15557.

(12) Erstad, D. J.; Ramsay, I. A.; Jordan, V. C.; Sojoodi, M.; Fuchs, B. C.; Tanabe, K. K.; Caravan, P.; Gale, E. M. Tumor Contrast Enhancement and Whole-Body Elimination of the Manganese-Based Magnetic Resonance Imaging Contrast Agent Mn-PyC3A. Invest. Radiol. 2019, 54, 697-703.

(13) Garda, Z.; Molnár, E.; Kálmán, F. K.; Botár, R.; Nagy, V.; Baranyai, Z.; Brücher, E.; Kovács, Z.; Tóth, I.; Tircsó, G. Effect of the Nature of Donor Atoms on the Thermodynamic, Kinetic and Relaxation Properties of 
Mn(II) Complexes Formed With Some Trisubstituted 12Membered Macrocyclic Ligands. Front. Chem. 2018, 6, 232.

(14) Drahoš, B.; Kotek, J.; Hermann, P.; Lukeš, I.; Tóth, É. $\mathrm{Mn}^{2+}$ Complexes with Pyridine-Containing 15Membered Macrocycles: Thermodynamic, Kinetic, Crystallographic, and ${ }^{1} \mathrm{H} /{ }^{17} \mathrm{O}$ Relaxation Studies. Inorg. Chem. 2010, 49, 3224-3238.

(15) Drahoš, B.; Lukeš, I.; Tóth, É. Manganese(II) Complexes as Potential Contrast Agents for MRI. Eur. J. Inorg. Chem. 2012, 1975-1986.

(16) Garda, Z.; Forgács, A.; Do, Q. N.; Kálmán, F. K.; Timári, S.; Baranyai, Z.; Tei, L.; Tóth, I.; Kovács, Z.; Tircsó, G. Physico-Chemical Properties of $\mathrm{Mn}^{\mathrm{II}}$ Complexes Formed with Cis- and Trans-DO2A: Thermodynamic, Electrochemical and Kinetic Studies. J. Inorg. Biochem. 2016, 163, 206-213.

(17) Forgács, A.; Tei, L.; Baranyai, Z.; Tóth, I.; Zékány, L.; Botta, M. A Bisamide Derivative of [Mn(1,4-DO2A)] Solution Thermodynamic, Kinetic, and NMR Relaxometric Studies. Eur. J. Inorg. Chem. 2016, 11651174.

(18) Botár, R.; Molnár, E.; Trencsényi, G.; Kiss, J.; Kálmán, F. K.; Tircsó, G. Stable and Inert Mn(II)-Based and pHResponsive Contrast Agents. J. Am. Chem. Soc. 2020. $142,1662-1666$

(19) Gale, E. M.; Wey, H.-Y.; Ramsay, I.; Yen, Y.-F.; Sosnovik, D. E.; Caravan, P. A Manganese-Based Alternative to Gadolinium: Contrast-Enhanced MR Angiography, Excretion, Pharmacokinetics, and Metabolism. Radiology 2018, 286, 865-872.

(20) Wang, J.; Wang, H.; Ramsay, I. A.; Erstad, D. J.; Fuchs, B. C.; Tanabe, K. K.; Caravan, P.; Gale, E. M. Manganese-Based Contrast Agents for Magnetic Resonance Imaging of Liver Tumors: Structure-Activity Relationships and Lead Candidate Evaluation. J. Med. Chem. 2018, 61, 8811-8824.

(21) Islam, Md. K.; Kim, S.; Kim, H.-K.; Park, S.; Lee, G.-H.; Kang, H. J.; Jung, J.-C.; Park, J.-S.; Kim, T.-J.; Chang, Y. Manganese Complex of Ethylenediaminetetraacetic Acid (EDTA)-Benzothiazole Aniline (BTA) Conjugate as a Potential Liver-Targeting MRI Contrast Agent. $J$. Med. Chem. 2017, 60, 2993-3001.

(22) Rolla, G.; De Biasio, V.; Giovenzana, G. B.; Botta, M.; Tei, L. Supramolecular Assemblies Based on Amphiphilic $\mathrm{Mn}^{2+}$-Complexes as High Relaxivity MRI Probes. Dalton Trans. 2018, 47, 10660-10670.

(23) Troughton, J. S.; Greenfield, M. T.; Greenwood, J. M.; Dumas, S.; Wiethoff, A. J.; Wang, J.; Spiller, M.; McMurry, T. J.; Caravan, P. Synthesis and Evaluation of a High Relaxivity Manganese(II)-Based MRI Contrast Agent. Inorg. Chem. 2004, 43, 6313-6323.

(24) Miller, J. H.; Powell, J. E. Synthesis and Lanthanide Complex Formation Constants of N'Benzylethylenediamine-N,N,N'-Triacetic Acid. Inorg. Chem. 1978, 17, 774-776.

(25) Szabadka, O. Determination of Protonation- and Metal Complex Stability Constants for a Chelating Monomer and Its Immobilized in Polymer Resin. Talanta 2003, 59, 1081-1088.

(26) Tse, P. K.; Powell, J. E. Study of Structural Influence on the Formation Constants of Lanthanide-Polyamino Polycarboxylate Complexes. Inorg. Chem. 1985, 24, 2727-2730.

(27) Kim, W. D.; Hrncir, D. C.; Kiefer, G. E.; Sherry, A. D. Synthesis, Crystal Structure, and Potentiometry of Pyridine-Containing Tetraaza Macrocyclic Ligands with
Acetate Pendant Arms. Inorg. Chem. 1995, 34, 2225 2232.

(28) Tircsó, G.; Kovács, Z.; Sherry, A. D. Equilibrium and Formation/Dissociation Kinetics of Some $\mathrm{Ln}^{\mathrm{III}}$ PCTA Complexes. Inorg. Chem. 2006, 45, 9269-9280.

(29) Rodríguez-Rodríguez, A.; Garda, Z.; Ruscsák, E.; Esteban-Gómez, D.; de Blas, A.; Rodríguez-Blas, T.; Lima, L. M. P.; Beyler, M.; Tripier, R.; Tircsó, G.; Platas-Iglesias, C. Stable $\mathrm{Mn}^{2+}, \mathrm{Cu}^{2+}$ and $\mathrm{Ln}^{3+}$ Complexes with Cyclen-Based Ligands Functionalized with Picolinate Pendant Arms. Dalton Trans. 2015, 44, 5017-5031.

(30) Regueiro-Figueroa, M.; Ruscsák, E.; Fra, L.; Tircsó, G.; Tóth, I.; de Blas, A.; Rodríguez-Blas, T.; Platas-Iglesias, C.; Esteban-Gómez, D. Highly Stable Complexes of Divalent Metal Ions $\left(\mathrm{Mg}^{2+}, \mathrm{Ca}^{2+}, \mathrm{Cu}^{2+}, \mathrm{Zn}^{2+}, \mathrm{Cd}^{2+}\right.$ and $\mathrm{Pb}^{2+}$ ) with a Dota-Like Ligand Containing a Picolinate Pendant: Complexes of Dota-Like Ligand Containing a Picolinate Pendant. Eur. J. Inorg. Chem. 2014, 61656173.

(31) Swift, T. J.; Connick, R. E. Erratum: NMR-Relaxation Mechanisms of ${ }^{17} \mathrm{O}$ in Aqueous Solutions of Paramagnetic Cations and the Lifetime of Water Molecules in the First Coordination Sphere. J. Chem. Phys. 1964, 41, 2553-2554.

(32) Gale, E. M.; Zhu, J.; Caravan, P. Direct Measurement of the $\mathrm{Mn}(\mathrm{II})$ Hydration State in Metal Complexes and Metalloproteins through ${ }^{17} \mathrm{O}$ NMR Line Widths. J. Am. Chem. Soc. 2013, 135, 18600-18608.

(33) Esteban-Gómez, D.; Cassino, C.; Botta, M.; PlatasIglesias, C. ${ }^{17} \mathrm{O}$ and ${ }^{1} \mathrm{H}$ Relaxometric and DFT Study of Hyperfine Coupling Constants in $\left[\mathrm{Mn}\left(\mathrm{H}_{2} \mathrm{O}\right)_{6}\right]^{2+}$. RSC Adv. 2014, 4, 7094.

(34) Pujales-Paradela, R.; Carniato, F.; Esteban-Gómez, D.; Botta, M.; Platas-Iglesias, C. Controlling Water Exchange Rates in Potential $\mathrm{Mn}^{2+}$-Based MRI Agents Derived from $\mathrm{NO}_{2 \mathrm{~A}^{2-}}$. Dalton Trans. 2019, 48, 39623972.

(35) Baroni, S.; Colombo Serra, S.; Fringuello Mingo, A.; Lux, G.; Giovenzana, G. B.; Lattuada, L. Synthesis and Relaxometric Characterization of a New Mn(II)-EDTADeoxycholic Acid Conjugate Complex as a Potential MRI Blood Pool Agent. ChemistrySelect 2016, 1, 16071612.

(36) Forgács, A.; Tei, L.; Baranyai, Z.; Esteban-Gómez, D.; Platas-Iglesias, C.; Botta, M. Optimising the Relaxivities of $\mathrm{Mn}^{2+}$ Complexes by Targeting Human Serum Albumin (HSA). Dalton Trans. 2017, 46, 8494-8504.

(37) Gale, E. M.; Caravan, P. Gadolinium-Free Contrast Agents for Magnetic Resonance Imaging of the Central Nervous System. ACS Chem. Neurosci. 2018, 9, 395397.

(38) Irving, H. M.; Miles, M. G.; Pettit, L. D. A Study of Some Problems in Determining the Stoicheiometric Proton Dissociation Constants of Complexes by Potentiometric Titrations Using a Glass Electrode. Anal. Chim. Acta 1967, 38, 475-488.

(39) Zékány, L.; Nagypál, I. Psequad. In Computational Method for Determination of Formation Constants; Legett, D. J., Eds.; Plenum: New York, 1985; Vol. 1, pp 291-353.

(40) Muller, R. N.; Radüchel, B.; Laurent, S.; Platzek, J.; Piérart, C.; Mareski, P.; Vander Elst, L. Physicochemical Characterization of MS-325, a New Gadolinium Complex, by Multinuclear Relaxometry. Eur. J. Inorg. Chem. 1999, 1949-1955. 
(41) Meiboom, S.; Gill, D. Modified Spin-Echo Method for Measuring Nuclear Relaxation Times. Rev. Sci. Instrum. 1958, 29, 688-691.

(42) Micskei, K.; Helm, L.; Brucher, E.; Merbach, A. E. Oxygen-17 NMR Study of Water Exchange on Gadolinium Polyaminopolyacetates $\left[\mathrm{Gd}(\mathrm{DTPA})\left(\mathrm{H}_{2} \mathrm{O}\right)\right]^{2-}$ and $\left[\mathrm{Gd}(\mathrm{DOTA})\left(\mathrm{H}_{2} \mathrm{O}\right)\right]^{-}$Related to NMR Imaging. Inorg. Chem. 1993, 32, 3844-3850. 
SYNOPSIS TOC

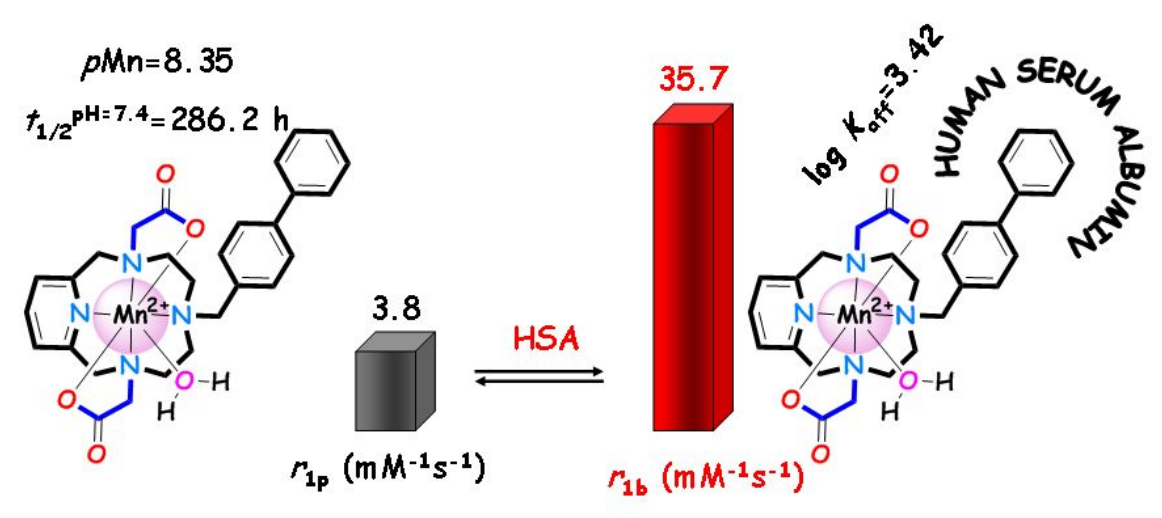

